\title{
The Comic OF THE Heroes - a Case Study of the Role of Humour in Reflecting National Identity
}

\begin{abstract}
The paper deals with the role of humour in relation to myth-making in a small nation. Analysing an essay by a modern Slovak historian, the text documents how the collective awareness of the national insignificance of a community in search of its identity can be subject to subtle comic treatment. With the help of the methodology of conceptual blending theory, I show how incongruity as the main source of humorous effect is triggered by the linguistic structures including grammatical functions and semantic roles (agent/patient) as well as the narrative structure. I argue that humour can help the community to cope with its awareness of marginality, which is articulated through the community's preoccupation with stressing its historical roots and cultural achievements to prove its European/global significance. Humour thus contributes towards the articulation and refinement of the community's self-perception of its national identity by critically reflecting and questioning on some of the collective myths that circulate within the community.
\end{abstract}

Key words

Conceptual blending theory; humour; national identity; collective self-perception; semantic roles

\section{Introduction}

The theme of a small nation suffering from inferiority complex and struggling for recognition on a global scale is not confined to the Slovak nation. In the European context, it is largely intermingled with the East-West opposition, and its uncivilized 
/ civilized mapping. Božićová, Vrbančić and Orlićová (2012: 60) point to the connection between the common conceptions of the Balkans as 'uncivilized' and the earlier 'inferiority' narratives that emerged in the period of the Enlightenment, which "created a boundary dividing 'Western superior civilization' from 'inferior Eastern barbarism"'. Investigating Central and Eastern European identity narratives, Melegh (2006) attributes what he calls 'East-West slope' a decisive factor in shaping identity narratives in Central Europe.

Kohák (2012: 25), reflecting on one of the most significant Czech philosophers Patočka, highlights the 'smallness' of the Czech nation as a leading, even fatal, force in historical decisions on the collective level. In connection with the capitulation of Beneš in the thralls of the Second World War, he concludes: "[z]ávěr je jednoznačný: malost českého údělu tu beznadějně porazila záblesk velikosti českého úkolu" [the conclusion is clear: the smallness of the Czech destiny has irrevocably defeated a spark of greatness of the Czech task]. In the Slovak context, a similar case in point would be the controversy over the personality of Jozef Tiso and his role in the first wartime Slovak Republic (cf. Kamenec 1998). Somehow, the Slovak nation has never quite succeeded in asserting itself and the collective psyche seems to be lacking a working, unifying hero myth, which could lay the foundation stone of healthy pride. The vacant slot is filled in two main ways - by chauvinism on the one hand, and humour on the other. In my paper, I will deal with the latter by analyzing the sources and effects of humour underlying a historical account of the Slovak historian Lubomír Lipták on changing ideologies and their symbols represented by statues and memorials.

In numerous accounts that originated in the field of psychology in the last century (Freud, Maslow, Allport to name but the most illustrative), humour is associated with psychological health and strength, functioning as a defence mechanism. Martin (1998) distinguishes between various forms of humour drawing on non-hostile, adaptive personality traits on the one hand, and its maladaptive forms linked to aggression on the other, claiming that humour as a part of positive psychology would be of the former kind. Ruch (1998: 7) points to the fact that the meaning of the term, while still in flux, has extended to cover a whole range of uses, where "coping humour is part of what was once understood as humour alone". In this way, humour can be understood as cognitive mastery (cf. Levine 1977), and, used with skill and intelligence, it could serve as a ground for coping with an inferiority complex of a small nation. It is particularly pronounced when a group faces adversity, and can be viewed as a character strength (cf. Peterson and Seligman (2004)). Humour can thus act as a corrective mechanism to the influx of self-deprecatory as well as self-aggrandizing collective attitudes when dealing with the national history, and it is the purpose of the present account to show, on particular linguistic material, how this can be achieved and what underlying cognitive mechanisms in place are involved. The central question therefore is how such humorous attitude is transmitted and what its effects on the reader might be. 


\section{Data}

... a my sme [duchovnú energiu] strácali pri hl'adaní génia loci slovenského územia. Tento nudný romantizmus je určite charakteristický pre stredoeurópsky región..., ale čo ten romantizmus ludstvu priniesol? Len ten padák sme vynašli, aj to nie u nás na Slovensku, ale v USA, hoci ho vynašiel Slovák - možno so zmyslom pre romantizmus vol'ného pádu. (Sloboda 2010: 112)

[... and we were wasting [energy] looking for the genius loci of the Slovak region. Such boring romanticism is certainly characteristic of Central Europe..., but how has humanity profited from it? Parachute is the only thing we invented, even that not here in Slovakia, but in the USA, although it was invented by a Slovak - perhaps with a sense of the romanticism of the fall of the bodies.]

The quoted words can be viewed as mirroring the basic predicament of the collective mind of a relatively small nation with relatively short and, from a global perspective, rather insignificant history. There are hardly any Slovak heroes of world merit the nation could cling to for sustaining one of the basic archetypal myths - the hero myth. Even if various attempts at fabricating such a myth out of raw historical data have been sprouting at different periods throughout history (the last wave taking place in the 1990s when Slovak Republic was declared), they all fail to be authentic and invite controversy. In this context, the text selected for analysis - Rošády na piedestáloch by Luubomír Lipták - offers a fresh look at the historical personalities assigned with the role of national heroes, as well as how they are treated by the respective political elites. Its English translation appeared in a collection of contemporary Slovak essays with the title Monuments of Political Changes and Political Changes of Monuments (1999b), and the examples quoted make use of the published translation.

Lipták (1930-1995) was a respected Slovak historian whose theoretical work managed to overcome ideological barriers of the communist regime. After 1968, his polemical and problematizing insights into historical issues resulted in a dismissal from the Slovak Academy of Sciences and a twenty-year long total or partial ban on publishing. His writing is marked not only by the complexity of a thinker independent of rigid ideological frameworks, but also by originality of expression. While never cutting corners in terms of academic rigour, a lot of Lipták's work takes an essayistic form, which is also the case of the text selected for analysis.

Rošády na piedestáloch is an account of frequent political changes that accompanied the Slovak nation on its way from early attempts at self-constitution up to the formation of the Slovak Republic in 1993. Lipták's focus is on the monuments and memorials, and their particular destinies following changes in political power, or the circumstances of their disappearance and return. With an undertone of humour and self-irony, he shows how susceptible the idols we worship are to 
changes of ideology. Great heroes are raised and knocked down from plinths, as need be. They are presented almost as caricatures, fallible figures that reflect our own helplessness and prompt us to laugh.

\section{Methodology}

As has been noted, the study of humour largely falls under the domain of psychology. However, since a significant part of humour is based on language, it is only natural that psycholinguistics should play a prominent role in any research targeting humour. As indicated by Martin (2007: 84) in his attempt at an integrative approach to the psychology of humour, "[o]ver the past two decades, there has been a flurry of renewed theoretical activity coming particularly from scholars in linguistics". He fully recognizes the role of schema theory in understanding how humorous incongruity is processed. Indeed, incongruity seems to act as one of the central principles in the analysis of humorous effect, involving semantic scripts that are mutually incompatible. The number and complexity of ordering of such scripts is varied - Raskin (1979: 333) states that in case of more complicated, and usually better jokes, "several overlaps [of scripts] occur simultaneously, often in a certain hierarchy". Humorous effect is then catalyzed by "triggers which serve as a signal that a competing script should be discovered and taken into account for the comprehension of the text" (Raskin 1979: 329). In terms of competing approaches to the analysis of humour, Dynel (2009: 2) highlights the incongruity resolution approach as the "prevailing model in contemporary humour literature".

Although, clearly, humour targets the emotional level (see Veatch's (1998: 163-164) affective commitment to the normalcy of a situation and its violation), it needs to be recognized that the actual trigger comes from the realm of cognition. If we use insights into conceptual blending from cognitive linguistics (cf. Fauconnier 1999, Fauconnier and Turner 2000, 2002) to account for the cognitive processes at work, it can be argued that the mapping taking place provides for a new insight by recruiting meaning from incongruent fields. This involves studying cognitive mechanisms not immediately accessible to our conscious thought:

Almost invisibly to our consciousness, conceptual blending choreographs vast networks of conceptual meaning, yielding cognitive products that, at the conscious level, appear simple. The way we think is not the way we think we think. (Fauconnier and Turner 2002: v)

One of the core premises is the human faculty of imagination which employs the so called mapping schemes to combine concepts into blends with new meanings. While the products of blending are not predictable from the forms that gave rise to them, this is not the case with the mappings, which can be inferred from the respective linguistic manifestations (cf. Fauconnier and Turner 2002: 147). For the purposes of research, this means that we have access to the mappings in opera- 
tion, and by their examination we can arrive at the cognitive processes operating "behind the scenes".

\section{Roots of humour - the case of migratory Hummel}

To demonstrate the principles of incongruity understood as blending of incompatible semantic scripts, let us consider the following example from the Lipták's text where such an incongruity appears in relation to a statue of an Austrian composer that was removed to a different location in Bratislava:

\section{st’ahovavý Hummel [migratory Hummel]}

Here, the attribute migratory triggers an image of a bird that changes its dwelling with the changing seasons, while Hummel denotes a statue. The apparently contradictory conflation of the semantic qualities of SELF-PROPELLED MOTION with STATIC EXISTENCE constitutes a violation to the basic image we have of the referent of the phrase - a statue as an object that cannot move of its own accord. On the level of visual perception, the image of statues flying like migratory birds to adapt to changing seasons produces a comic effect. The comic effect originates precisely from the fact that the image of statues migrating by air (a violation) and the image of statues as stable, immovable objects work simultaneously in our mind. As Veatch (1998: 164) puts it, "humor occurs when it seems that things are normal while at the same time something seems wrong". On a more complex level, humorous effect rests on an interplay of the creative word combination with the cultural context - notably the practice of removing statues that commonly occurs at times of major changes in the history of nations, as was the case in the early 1990s in Slovakia and other countries of Central and Eastern Europe.

What appears crucial in the analysis of the mental spaces that feature in conceptual blending theory are the truth values. As Fauconnier argues, we need to distinguish between actuality, potential and a lack of either:

Because [mental] spaces contain elements with assigned properties, they have a potential for acquiring real-world truth values under specific matchups of elements with objects. And yet the configurations can be operated on to yield inferences and additional structure without instantiating any of the potential matchups $[\ldots]$ this feature of space construction is a major factor behind some unusual aspects of human creativity. (Fauconnier 1997: 69)

As humour can be viewed as such an unusual aspect of human creativity, this means that an additional structure is created by configuring two structures that potentially have real-world truth values. Such additional structure does not need to rest on even a potential match-up. And yet, 
[t]he manipulation of space configurations in the absence of a real-world match-up would be no more than a solipsistic exercise were it not for the crucial implicit assumption that we know in principle how to match worlds with configurations. (Fauconnier 1997: 69)

This means that if humorous effect is to be achieved, the blending mechanisms must be grounded in existing cognitive structures "knowledge of which is presupposed for the concepts encoded by the words" (Fillmore and Atkins 1992: 75).

How exactly such unusual meaning comes about was investigated by Fauconnier and Turner (2002) who put forth a theory of integration networks to account for emergent meaning. Here, several input spaces are linked via a generic space, whose level of abstraction is such that it can accommodate all the inputs. Moreover, this is also the path through which the unusual meaning is tied to the emotions, as the conceptual projections and mappings that facilitate the constitution of meaning correspond to neural coactivations and bindings. (Fauconnier and Turner 2002: 46) To come back to the example of migratory Hummel, the phrase can be translated into the proposition

\section{STATUE IS A MIGRATORY BIRD,}

where two input spaces can be identified, represented by the conceptual metaphor STATUE and MIGRATORY BIRD. The crucial element in the generic space would be provided by AGENT that can be mapped onto an inanimate object which is contained by the mapping HISTORICAL PERSONALITY - STATUE. The other generic elements would be PATH and CYCLE.

In essence, an application of the specific humour 'schema' just described could generate an infinite number of similar pre-modifier + head noun phrases with elements that would fit the given semantic pattern, such as migratory lamps. While certain humorous effect could still be achieved, its intensity would be quite low compared to the example above. This leaves us with the question of why certain structures, being analogous to other structures, are more humorous than their counterparts.

Veatch (1998) identifies three factors that add intensity to the effect of humour: the degree of complexity, vividness of violating interpretations and level of pleasure achieved by normalcy interpretations. First, the complexity is introduced through the socio-cultural context which facilitates a re-interpretation of the concrete image through a set of metaphoric representations. Given the thematic structure of the text, the statue is conceived as a symbol of ideology. From the synchronic point of view, ideology is perceived as a stabilizing, even fossilizing social force unless a revolution or another power takeover is taking place. Nevertheless, from a larger, diachronic perspective, it is inevitably subject to change, and history tells us that no ideology has ever attained eternal life. This observation informs the conceptual metaphor CHANGING IDEOLOGIES ARE HISTORICAL CYCLES. Therefore a more global insight is reached, one which re-normalizes the logical paradox on the affective level. 
Another factor that adds to the intensity of humorous effect is compatibility with reader experience - here at least the experience of those readers who have lived through one or more of the multiple overturns of government and the ensuing 'overturns' of the marble heroes of the preceding regime. Hence, the more one has been witness to radical shifts in physical symbols of various regimes, the more vivid the image, and therefore the more intense the humorous effect. In Veatch's words,

familiarity with and intensity of the violation have an important role. People sometimes find a situation or a joke more funny when it evokes an experience they have had before. (Veatch 1998: 181)

In this case, what plays crucial role is the collective experience with the national history as translated into individual minds, i.e. the degree to which one is conscious of the history of his/her nation. According to Talmy (2003: 418)

a perceiver regularly construes the external events she has witnessed over a period of time as narrative - a type that might be termed 'history'. And a perceiver regularly construes the sequence of personal experiences he has had over time - both interior and externally based experiences - as constituting a narrative, that of his 'life'.

The term narrative is used in a broad sense here, which is common to 'experientialist' approaches common to cognitive linguistics. As pointed out by Johnson (1997: 163)

[n] arrative $[\ldots]$ is not merely linguistic or textual. ... narrative characterizes the synthetic character of our very experience, and it is prefigured in our daily activities and projects. The stories we tell emerge from, and can refigure, the narrative structure of our experience.

It is the extent to which the 'history' narrative located on the national level is conflated with the 'life' narrative of an individual reader that provides for intensification of humorous effect in Lipták's text, thus refiguring the narrative structure of our experience.

Third, humorous effect is amplified by the pleasure derived from a violation of the dignity of a disliked 'other' - as is often the case with authorities. As noted by Veatch (1998: 181), "a violation of the dignity, comfort, etc., of a disliked character seems to be acceptable, gratifying, and positively pleasurable to humans". In this connection, Freud (2005: 89-90) speaks of delight principle with a joke allowing us to see what is funny about the enemy, which we were unable to give a voice to due to certain obstacles on the way - the joke thus bypasses limitations and opens up forbidden sources of delight. In other words, humour has the potential to change the viewpoint from what was, at the emotional level, suffering and 
humiliation into what is now delight. It is the vehicle that makes delight accessible; it is a sort of rebellion against authority that frees one from its pressure (cf. Freud 2005: 91), and humour replaces feelings of inferiority by feelings of superiority (cf. Veatch 1998: 188). In consequence, the more an authority is despised and felt as oppressive, the more intense the humorous effect.

Such straightforward mechanism can, however, be complicated when self is included in the target of humour, and self-irony ensues. The above quoted example is a case in point. Hummel, an Austrian composer, whose statue was erected by lovers of his music, does not represent a despised political authority. In fact, the monument has to be moved to make space for "the more representative, and especially more 'Hungarian' Petöfi” (Lipták 1999b: 115). This turns the principle of delight as described above upside down, as Hummel's migratory status, which is the most direct source of the comic effect as it works on the image level, could actually now be identified as a victim of authority rather than a despised authoritarian figure to laugh at. In fact, he gives space to a figure that represents the Hungarian oppressors in a comic way. Such contextualization blocks the feeling of superiority on the one hand, while letting on board the cathartic effect of the comic. In this sense, self-irony adds another layer of complexity to the perception of humour, which, in psychological terms, internalizes the negative 'other' and integrates it into the conscious attitude in an acceptable way.

In fact, the defining feature of humour both on the cognitive and on the affective level - i.e. simultaneity of contradictory views - could be seen as a property of art. According to Zeki (2006: 243), ambiguity is "characteristic of much of great art, an attribute that heightens substantially the artistic and aesthetic merit of a work". In a sense, art allows us to hold opposites in the mind and accept them on the emotional level. Humour as a technique can thus be viewed as an organizing form that employs a conceptual metaphor which provides a link to the patterns inherent to our visual imagery. Like thinking, it "cannot go beyond the patterns suppliable by human senses" (Arnheim 1969: 233, op. cit. Lakoff 2006: 154). As opposed to conventional thinking, though, the patterns are conflated via a contradictory feature they each display and it is the very ambiguity used as a cognitive glue that provides for the effect on the affective level. If used creatively and with intensity, the effect of humour is similar to that of good art - it offers a holistic perception by uniting conflicting opposites, which is cathartic.

\section{Monuments as characters and their physical life}

In fact, it is upon the portrayal of the monuments and their statue 'life', and its intermingling with the actual historical personalities that the imagery sourcing the humorous effect mainly rests. These actually become the characters in the overall plot, playing a crucial role in the progression of events that fulfil "some purpose or mission on the part of the author" (Talmy 2003: 427). From the point of view of grammar, this happens either directly in the capacity of agentive participants, 
subjects of clauses where agents are not expressed or subjects of passive clauses, which actually occupy most of the subject positions in the clauses ${ }^{1}$. The following analysis should shed light on the ambiguity of reference related to the characters, and the ensuing humorous effect.

Respecting the prototypical semantic role of the clausal subject, which is agent (most typically human), the prototypical situation (the situation that provides us with the normalcy reference frame) could be represented by the structure

\section{HUMAN raised MONUMENT}

with the AGENT (human being) exerting intentional control over patient (inanimate object). Any change to this pattern would signal a change of focus away from the prototype. The passive construction,

\section{MONUMENT was raised by HUMAN}

however 'normal' it may sound, by shifting the order of the arguments, forces attention to change its natural focus, thus instigating a marked structure (cf. Evans, Green 2011: 765).

The focus of attention on patient is even greater in the situations where the agent is not expressed, i.e.

\section{MONUMENT was raised}

In fact, all of the passive structures in the analyzed text ( 21 in total) comply with the latter pattern, i.e. none of the actual agents of the processes described are expressed. With Slovak flexible word order, however, the motivation for employing a passive structure, i.e. to change the order of arguments, which is strongly present in English with its fixed word order, does not play such a significant role. This can be demonstrated by the following sentence:

Vo Vel'kých Vozokanoch bol roku 1896 odhalený vel'ký pomník bitky s Turkami roku 1621, pri ktorej padli štyria Eszterházyovci.

with its English translation running:

[In 1896 a large monument to the $\mathbf{1 6 2 1}$ battle with the Turks in Vel'ké Vozokany, at which four Eszterházys fell, was unveiled.]

1 A five page sample calculation of monuments versus actual social actors (such as vláda robotnikov a rolnikov, vláda, režim, ludia [the government of workers and peasants, the government, the regime, the people]) in the position of subject of a verbal clause reveals the ratio of 35 to 14 , which is more than twice the number. Only overt subjects were counted. 
While it is true that in Slovak using a passive structure relieves the speaker from expressing the number and gender of the 'energy source', such motivation is not relevant in the present context where it is presumed that monuments are raised by collectives rather than individuals, which means that an active structure

Vo Vel'kých Vozokanoch odhalili roku 1896 vel'ký pomník bitky s Turkami roku 1621, pri ktorej padli štyria Eszterházyovci.

[...they unveiled...]

would, from the point of view of arguments, serve an almost identical function. Coming from this premise, it can be claimed that, irrespective of the voice of the utterance, wherever agentive subject is not expressed, the same function of backgrounding of the 'energy source' is served. Moreover, the flexible word order allows for end-focus in terms of information structure, while rhematic status (cf. Firbas 1992) is signalled by an indefinite article in the English translation. Regarding the English version, if both end-focus and indefinite article were to work in unison to stress the rhematic position of the monument, it could no longer preserve its subject category, as an overt agentive subject would have to be introduced

In 1896 the authorities unveiled a large monument to the 1621 battle with the Turks in Vel'ké Vozokany, at which four Eszterházys fell.

This points to the fact that structurally, Slovak disposes of more options to background the actual energy source, as the subject need not be overtly expressed, which means that structural characteristics of Slovak contribute to Lipták's strategy of ambiguity as to the intentional agents of the processes.

In fact, the frequency with which subjects are occupied by the monuments (around $70 \%$ of the cases) shows the degree to which the actual instigators of the processes (political authorities and other stakeholders) recede into the background, i.e. the degree to which the prototypical flow of attention is inverted. This, in itself, does not provide for humorous effect on a local (phrase) level, however, by letting the monuments act as subjects of clauses, they assume the role of the main characters in terms of the narrative and its plot, which means it is (mainly) them who moves the story further. This has implications for the reader's attention, which is now predominantly governed by the question 'What do the monuments do?', rather than 'What is done to the monuments?', i.e. they are perceived as the agent rather than patient. This constitutes the major framing operating on a more global level of narrative. The following passage extracted from the introduction could illustrate the point:

Zhromaždené sochy neboli vel'diela, tie z bronzu a od známych majstrov boli asi niekde inde, tu boli Fidrichovia tak povediac radoví, z lacného materiálu. Boli dokladom nemeckej pedantnosti, že ich niekde nezapatrošili, 
ale ich stav ukazoval, že predsa len sme v akomsi, inom Nemecku'. Patrilo by sa, aby aspoň stáli v rade, na poriadku, ležali však a postávali, ktorý ako. Niektorí, zrejme zosadení z koňa, dokonca $\mathrm{v}$ akomsi podozrivom podrepe. Jedni kráčali nevedno kam, iní ukazovali pravicou s mečom i bez kamsi do dial'av. Vinou neporiadku alebo s akýmsi hlbším zmyslom a podtónom ukazovali a velili k útoku na všetky svetové strany. Jeden, zvalený na chrbát, ukazoval dokonca do nebies, takže sa človek mimovol'ne zahl'adel, čo tam letí?

[The assembled sculptures were not masterpieces, the bronze ones by famous sculptors were probably somewhere else, here were so-to-say ordinary Fredericks, made of cheap materials. It was testimony to the Germans' pedantism that they had not misplaced them, although their condition showed that we really were in a 'different Germany'. It would have been fitting if they had at least stood in a line, neatly, but some lay and others stood. Several, probably dismounted from a horse, were even in a suspicious half squat. Some were walking who knows where, others were pointing into the distance with or without a sword in their right hand. Either because of the untideness or some deep meaning or undertone they pointed and signalled attack in all directions. One, lying on his back, was even pointing to heaven, making one subconsciously stare up at the sky to see what was flying there.]

Here statues which represent the denotative meaning of the subjects marked by bold are enlivened in two major ways. First, the metaphor EVENTS ARE ACTIONS is applied to the image of an 'assembly' of sculptures. Such a metaphor acts as 'a systematic way of constructing blends in accordance with the governing principles that intensify and create vital relations' (Fauconnier, Turner 2002: 349) and in fact facilitates the construal of sculptures as entities involved in the process of assembling. Another intensification of vital relations is achieved through the conceptual procedure called 'fictive motion', which

blends a dynamic scenario of motion with a static situation so that the static situation can be conceived and described as having motion (Fauconnier, Turner 2002: 349)

Such 'fictive motion' is triggered by verbs like postávali, kráčali, ukazovali, velili [stood, were walking, pointed, signaled attack]. Both EVENTS ARE ACTIONS metaphor and 'fictive motion' are the basic tools of creating intentionality, for which textbook examples could be 'Death took him' and 'The fence runs all the way down the river' respectively, and as such, the blends do not provide for humorous effect. Rather than being the source of humour, the 'vitalization' of relations provides an affective structure in which humour can crystallize. In Lakoff's words

[w] hen the pre-motor to motor connections are inhibited, the secondary pre-motor circuitry can function as a 'cog' - it can still compute complex 
patterns that permit inferences and evolve over time. Such patterns structure what we can see as form in art. (Lakoff 2006: 153)

It can therefore be argued that the activated patterns, by being both abstract and embodied (and therefore connected to affective functions) serve as the context for ambiguity involving violation, which is a necessary property of both humour and art.

\section{Pronominal reference and personification}

In the analyzed text, ambiguity is ultimately rooted in the subject reference. This can be illustrated if we consider the subjects (invariably with the semantic role of intentional agents) which denote the statues in the passage:

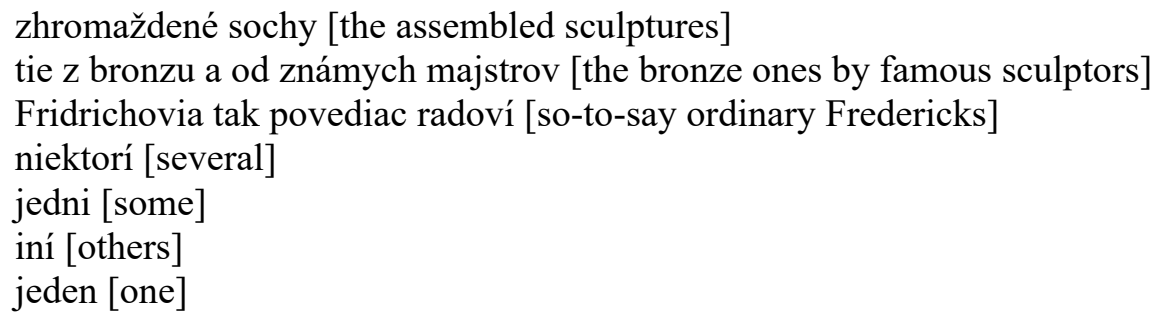

where we can trace the development from inanimate to animate entities, with the proper name used in plural (Fridrichovia [Fredericks]) serving as a bridge to introducing the semantic element HUMAN (niektori, jedni, ini, jeden [several, some, others, one]) as opposed to tie z bronzu a od známych majstrov [the bronze ones by famous sculptors]. The normalcy of there being a human historical personality and its contemporary embodiments in inanimate statues is violated by the plural reference creating a group of individuals that can be compared to one another (radovi [ordinary]) and that can each take part in an independent activity such as standing, pointing, lying, etc. In other words, the boundary between the actual person and its statue replicas is blurred by referring to them by the same proper name and giving them intentionality and therefore vitality. Such conceptual pattern is established from the beginning of the text ${ }^{2}$, and is then readily retrieved, like for example in relation to the Hungarian poet Petöfi and his statue that acts as a character in the narrative:

...v Bratislave tiež dalo vedenie mesta Petöfiho sochu zadebnit'. Takto bol ukrytý až do roku 1921, o jeho osude sa búrlivo diskutovalo. Niektorí sa ho snažili vyslobodit' z potupného debnenia poukazovaním na Petöfiho republikánske a demokratické cítenie, na to, že bol revolučný básnik a mal 
dokonca aj slovanský pôvod. Slovenský denník, orgán agrárnikov, však nekompromisne konštatoval, že ako renegát mal svoje miesto na bývalom Kossuthovom námestí, ale do terajších Palackého sadov sa nehodí. Je pravda, že bol republikánskeho zmýšl’ania, ale musí byt' ešte dlho zakrytý doskami, aby ho neoslavovali tí, čo chcú obnovit' habsburské panstvo. [...in Bratislava the town authorities had Petöfi statue boarded up. $\mathbf{I t}^{3}$ was hidden like that until 1921, while there was heated discussion about its fate. Some attempted to free him from the degrading boarding pointing out Petöfi's republican and democratic beliefs, that he was a revolutionary poet and was even of Slavic origin. But Slovenský denník, a farmer's newspaper, uncompromisingly stated that as a renegade he belonged on the former Kossuth Square, but had no place in today's Palacký Park. It is true that he had republican convictions, but he had to be hidden behind the boards for longer, so that he was not glorified by those who wanted to restore the Habsburg Monarchy.]

While in the first sentence of the quoted passage it is, explicitly and unambiguously, the statue that undergoes the process of boarding up, the verb in the second sentence of the Slovak original signals animate reference as masculine is used (bol ukrytý [was(masc.sg) hidden(masc.sg)] instead of feminine required for the anaphoric reference to the preceding socha [statue(fem.sg)]. The violation in place rests on the unclarity as to who was actually hidden and whose fate was actually discussed. Such dual status of the reference is further affirmed in the following sentence where the verb vyslobodit' [free] is forced into the material sense by the context to mean 'remove the physical barrier' - i.e. debnenie [the boarding], and yet the noun responsible for the concrete and physical meaning of the otherwise abstract verb takes on the premodifier potupný [degrading] which, by referring to emotions, attracts the human-centred reading already evoked by the animate pronoun ho [him] acting in the place of object.

On the level of text, the more metaphoric, or personified reading prevails, and can be regarded as more normal, which might also be documented by the decision of the English translator to switch to human reference signalled by the pronoun he. However, to the degree to which historical narratives refer to the facts of history, whatever their ontological status, there is a factual real-world truth matchup that enters the reader's cognition, i.e. the purely physical boarding up of an inamimate object (albeit with a symbolic value). It is precisely this real-world truth matchup on the one hand, and its absence on the other, that fulfils the condition of normalcy and violation simultaneously present in the mind of the reader. Such oscillation is upheld throughout the quoted passage, and culminates in the last

3 Note that the English translator has opted for re-establishing the normalcy by using neuter it and its reference for the statue. The switch to animate reference only occurs in the following sentence (him), perhaps influenced by the evaluative premodifier degrading in connection with the process of boarding, which, used in non-metaphoric sense, connotes a human (or at least animate) being. 
sentence where parallel verbal structure is accorded with the same subject of dual reference (statue/human being) - bol republikánskeho zmýšlania, ale musí byt' ešte dlho zakrytý doskami [he had republican convictions, but he had to be hidden behind the boards for longer]. In contrast to the well-established metaphor of historical personalities surviving their death on the ideational level, Lipták constantly evokes their survival on the material, physical plane. The constraints on their physical life are given by the constraints applicable to the material existence of statues and monuments, which leads to affective absurdity. The following examples can illustrate the point:

Horšie pochodil Štefánik, bol zničený, iba bronzovú hlavu skrýval skoro štyridsat' rokov občan ned'alekej obce.

[Štefánik fared worse, he was destroyed, only his bronze head was hidden by a citizen from a nearby village for almost forty years.]

Na pomníku v Ilave je partizán, ale pretože je rozkročený so zbraňou nad hlavou, samopal by bol prikrátky, musel sa uspokojit's flintou.

[On a monument in Ilava, there is a partisan, but since he is astride and holding his gun above his head, a machine gun would have been too short, so he had to do with a rifle.]

Bratislavský Gottwald dostal nápis ,vrah', ruky mu natreli červenou farbou. [The Bratislava Gottwald was given the inscription 'murderer' and his hands were painted red.]

By extending the physical life of the historical personalities and grounding it in the ensuing factual reality of the monuments and statues, the ideational leaders with their unique existence are downgraded into the roles of ordinary physical beings, part of the crowd, and their physical properties and physical processes in which they participate become exposed. The normalcy framing of giving a historical personality symbolic life after their physical death is violated, and instead of continuous existence on the ideational plane, their continuity is procured in the form of material vitalized presence.

\section{Concluding remarks}

It has been shown that, on the level of narrative, context for humour to crystallize is created by systematic granting of intentional agency to statues and monuments, thus making them into the main characters that move the plot further. Humour is then sourced by ambiguous reference as to the ontological status of the characters - oscillating between the actual historical personalities and their embodiments in the form of monuments. As the national heroes continue their physical existence through their after-life replicas, comic effect is reached by simultaneous violation 
and normalcy perception on the part of the reader. While using structures of cognitive mapping, humour operates on an affective level, creating a feeling of what Veatch (1998) calls affective absurdity. Such reversal on the emotional level has the potential to reconfigure inferiority as superiority, which might act as a mechanism for dealing with oppression on the psychological level.

Moreover, it has been argued that humorous effect is intensified by three main factors. First, the cognitive complexity of the context provides for the fact that humour operates on multiple planes, and, inter alia, serves as a comment on ruling ideologies. Second, it ties into the collective experience of the readers as witnesses to the reshuffling of ideological symbols. Last but not least, humour is intensified by the delight principle that springs from de-dignifying disliked characters - e.g. communist authorities. Further complexity is added by self-irony, where self becomes the target of humour. The negative 'other' is thus internalized and integrated into the conscious attitude in an acceptable way. The overall effect of Lipták's humour is cathartic on the psychological level, while intellectually, it provides a necessary distance from the phenomena observed.

\section{References}

Božićová, Senka, Vrbančić, Mario and Orlićová, Orla (2012) 'European cultural contesting identities (the case of Istria)'. In: Studer, Patrick and Iwar Werlen (eds.) Linguistic Diversity in Europe: Current Trends and Discourses. Berlin and Boston: De Gruyter Mouton, 49-68.

Dynel, Marta (2009) Humorous Garden-Paths. A Pragmatic-Cognitive Study. Newcastle upon Tyne: Cambridge Scholars Publishing.

Evans, Vyvyan, Green, Melanie (2011) Cognitive Linguistics. An Introduction. Edinburgh: Edinburgh University Press.

Fauconnier, Gilles (1997) Mappings in Thought and Language. New York: Cambridge University Press.

Fauconnier, Gilles, Turner, Mark (1999) 'Metonymy and conceptual integration'. In: Panther, Klaus-Uwe and Gunter Radden (eds.) Metonymy in Language and Thought. Amsterdam: John Benjamins, 77-90.

Fauconnier, Gilles, Turner, Mark (2000) 'Compression and global insight'. Cognitive Linguistics 11 (3-4): 283-304.

Fauconnier, Gilles, Turner, Mark (2002) The Way We Think. Conceptual Blending and the Mind's Hidden Complexities. New York: Basic Books.

Fillmore, Charles J., Atkins, Beryl T. (1992) 'Toward a frame-based lexicon: The semantics of RISK and its neighbours'. In: Lehrer, Adrienne and Eva Kittay (eds.) Frames, Fields and Contrasts I, Hilldale/H.J.: Lawrence Erlbaum Assoc., 75-102.

Firbas, Jan (1992) Functional Sentence Perspective in Written and Spoken Communication. Cambridge: Cambridge University Press.

Freud, Sigmund (2005) Vtip a jeho vztah k nevédomí. Praha: Psychoanalytické nakladatelství.

Johnson, Mark (1997) Moral Imagination. Implications of Cognitive Science for Ethics. Chicago and London: The University of Chicago Press.

Kamenec, Ivan (1998) Tragédia politika, kňaza a človeka (Dr. Jozef Tiso 1887-1947). Bratislava: Archa.

Kohák, Erazim (2012) 'Hledání české filosofie’. In: Kohák, Erazim (ed.) Hledání české filosofie. Praha: Filosofia, 13-34. 
Lakoff, George (2006) 'The neuroscience of form in art'. In: Turner, Mark (ed.) The Artful Mind. Cognitive Science and the Riddle of Human Creativity. Oxford: Oxford University Press, 153170.

Levine, Jacob (1977) 'Humour as a form of therapy: Introduction to symposium'. In: Chapman, Antony J. and Hugh C. Foot (eds.) It's a funny thing, humour. Oxford: Pergamon Press, 127-138. Lipták, Lubomír (1999a) Storočie dlhšie ako sto rokov. Bratislava: Kalligram.

Lipták, Lubomír (1999b) 'Monuments of Political Changes and Political Changes of Monuments'. (Translated by S. Miklošová) In: Kollár, Miroslav (ed.) Scepticism and Hope. Bratislava: Kalligram, $110-153$.

Martin, Rod A. (1998) 'Approaches to the Sense of Humour: a historical review'. In: Ruch, Willibald (ed.) The Sense of Humour. Explorations of a Personality Characteristic. Berlin and New York: Mouton de Gruyter, 15-62.

Martin, Rod A. (2007) The Psychology of Humour - An Integrative Approach. Burlington, MA: Elsevier Academic Press.

Melegh, Attila (2006) On the East/West Slope. Globalization, Nationalism, Racism and Discourses on Central and Eastern Europe. Budapest, CEU Press.

Peterson, Christopher, Seligman Martin E.P. (2004) Character Strengths and Virtues: A Handbook and Classification. Oxford and New York: Oxford University Press.

Raskin, Victor (1979) 'Semantic Mechanisms of Humour'. Proceedings of the Fifth Annual Meeting of the Berkeley Linguistics Society, 325-335.

Ruch, Willibald. (1998) 'Sense of Humour: A New Look at an Old Concept'. In: Ruch, Willibald (ed.) The Sense of Humour. Explorations of a Personality Characteristic. Berlin/New York: Mouton de Gruyter, 3-14.

Sloboda, Rudolf (2010) Záznamy. Bratislava: Fragment.

Talmy, Leonard (2003) Toward a Cognitive Semantics. Volume II: Typology and Process in Concept Structuring. London: MIT Press.

Veatch, Thomas C. (1998) 'A theory of Humor'. Humor 11(2): 161-215

Zeki, Semir (2006) 'The neurology of ambiguity'. In: Turner, Mark (ed.) The Artful Mind. Cognitive Science and the Riddle of Human Creativity. Oxford: Oxford University Press, 243-270.

\section{Sources}

Lipták, Lubomír (1999) 'Monuments of Political Changes and Political Changes of Monuments'. (Translated by S. Miklošová) In: Kollár, M. (ed.) Scepticism and Hope. Bratislava: Kalligram.

Lipták, Lubomír (1999) Storočie dlhšie ako sto rokov. Bratislava: Kalligram.

Danica Malekové is a lecturer at the Department of English Language and Literature, Catholic University, Ružomberok, Slovakia. She gained her PhD (2010) from the Masaryk University in Brno, Czech Republic with the dissertation titled The Genre of Institutional Press Release - A Critical Discourse Analysis. She has recently published the monograph Cultural Values in British and Slovak Tourist Texts: a Study of Evaluative Adjectives (2017). Her main teaching and research areas include comparative stylistics, cognitive approaches to language analysis and critical discourse analysis.

Address: Danica Maleková, PhD, Department of English Language and Literature, Faculty of Arts and Letters, Catholic University in Ružomberok, Hrabovská cesta 1, 03401 Ružomberok, Slovakia. [email: danica.malekova@ku.sk] 